TEGAR 4 (1) (2020) 1-4
Journal of Teaching Physical Education in Elementary School
Available online at :
https://ejournal.upi.edu/index.php/tegar/article/view/28363
DOI: https://doi.org/10.17509/tegar.v4i1.28363

\title{
Analyzing The Elementary School Student Cooperative Skill through Outbound Activities
}

\section{Lutfi Nur}

Prodi Pendidikan Guru Sekolah Dasar, UPI Kampus Tasikmalaya, Indonesia

\begin{tabular}{|c|c|}
\hline Article Info & Abstract \\
\hline $\begin{array}{l}\text { Article History: } \\
\text { Received : September } 2020 \\
\text { Accepted : September } 2020 \\
\text { Available Online : October } 2020\end{array}$ & $\begin{array}{l}\text { Cooperation is an important aspect to be owned by students to support their quality of } \\
\text { life. The purpose of this study was to find out the elementary school student coopera- } \\
\text { tive skill through outbound activities. The descriptive method was chosen to describe } \\
\text { the cooperative ability of } 20 \text { lower class students, aged 7-9 years. The data were col- }\end{array}$ \\
\hline $\begin{array}{l}\text { Keywords: } \\
\text { cooperation, cooperative skills, } \\
\text { elementary school students, outbound } \\
\text { activities. }\end{array}$ & $\begin{array}{l}\text { lected through an electronic instrument of cooperative rubric covering three aspects, } \\
\text { including communication, responsibility, and helping each other. The obtained data } \\
\text { were analyzed by using the descriptive statistical analysis to describe the cooperative }\end{array}$ \\
\hline & $\begin{array}{l}\text { student cooperative skill was very low. It was shown by the development of the score. } \\
\text { The score on the communication aspect was } 44 \% \text {. The score on the responsibility } \\
\text { aspect was } 29 \% \text {. The score on helping each other aspect was } 33 \% \text {. This condition } \\
\text { should become the evaluation for the elementary school teachers to find out an alter- } \\
\text { native solution to overcome the problems. In addition, technology utilization, such as } \\
\text { electronic rubric, could help teachers in conducting observation to evaluate the stu- } \\
\text { dent's learning development in elementary schools. }\end{array}$ \\
\hline
\end{tabular}




\section{INTRODUCTION}

In elementary school level, students are learners who need to be directed, developed, and facilitated to a more complex development. Therefore, education in the elementary school level is an education that mostly directs and motivates the students to learn (Dignath, Buettner, \& Langfeldt, 2008; Nur \& Malik, 2020). Elementary education helps the physical and spiritual developments so that the students are prepared to learn in the next level of education.

Physical Education at elementary school level not only focuses on motor movement goals, but also teaches the values of sports, such as cooperation (Rokhayati, Nur, Gandana, \& Elan, 2016; Nur, Hafina, Rusmana, Suryana, \& Malik, 2019). Cooperative skills become important as human, as a social being, cannot live alone and will need other people. Therefore, the introduction to and training of cooperative skills should become the consideration in the student learning. Melis \& Semmann (2010) explain that cooperation is the activity of two or more people to achieve the goals that have been decided before in a decided period of time. Furthermore, another research, (Lai, 2011) states that cooperation is a mutual involvement of a group as a coordination effort to solve the problem together shown by the interaction, such as the common goals, communication, negotiation, interdependence, etc.

Collaborating to learn and learning to collaborate is a term stated by (Lee, Huh, \& Reigeluth, 2015) which means that the collaboration to learn could help students to gain knowledge easier as the process is conducted in a group. In the interaction, there is a process to learn how to cooperate, thus the students could learn how to convey the goal or the willing of the group, how to communicate, how to be responsible, and other aspects that are needed in the daily life. Therefore, cooperative skills should be taught as early as possible (Pangrazi \& Beighle, 2019).

In this research, the researcher assumed that it is important for the teachers to know the cooperative skills of the students, especially students of lower classes regarding their development process. Therefore, the depiction of the data attainment result can be the evaluation for the teachers in implementing teaching methods. On the other hand, the rapid development of technology could facilitate the teachers in choosing the tools and media to ease the process of student performance evaluation, such as the use of electronic rubric (Nur, Setiadi, Kusdinar, \& Malik, 2019; Nur, Suherman, \& Subarjah, 2019). To gain information of the student cooperative depiction, the researcher chose outbound activities as most of the games are team games and the students can interact each other, thus it is easier to see the depiction of the student cooperation (Agusta, 2018; Azhima, 2020; Maryatun, 2008). Therefore, the researcher was interested to find out the description of the lower-class elementary school student cooperative skills by using an electronic rubric for the cooperation and outbound activity.

\section{METHOD}

This research employed descriptive method to describe the phenomena of a group without a specific treatment (Fraenkel, Wallen, \& Hyun, 2012; Malik \& Rubiana, 2019). The participants of the research were the lower-class elementary school students consisted of 20 students aged 7-9-year-old. The instrument used in this research was the cooperative skill electronic rubric covering three aspects, including communication, responsibility, and helping each other. The researcher used the achievement category table as can be seen in Table 1 and applied the descriptive statistics analysis technique to analyze the data.

\section{RESULT AND DISCUSSION}

The research was aimed at finding out the depiction of the cooperation condition of the lowerclass elementary school students covering three aspects, including communication aspect, responsibility aspect, and helping each other aspect. Table 1 shows all collected cooperation data of the 20 students.

Table 1. Student Cooperation Data Description

\begin{tabular}{lccc}
\hline & Aspect & & \\
\cline { 2 - 4 } & Communication & Responsibility & $\begin{array}{l}\text { Helping } \\
\text { Each } \\
\text { Other }\end{array}$ \\
\hline Total & 35 & 23 & 26 \\
Min & 1 & 1 & 1 \\
Max & 2 & 2 & 2 \\
Mean & 1.75 & 1.15 & 1.30 \\
SD & 0.44 & 0.37 & 0.47 \\
\hline
\end{tabular}

Table 1 shows that the communication aspect gained the highest score, 35 points. Meanwhile helping each other aspect and responsibility aspect only 
gained 26 and 23 points. In the minimum and maximum scores, all of them are the same, 1 and 2 scores. Meanwhile, the mean and standard deviation of each aspect assessment was $1.75 \pm 0.44$ for communication aspect, $1.15 \pm 0.37$ for responsibility aspect, and $1.30 \pm 0.47$ for helping each other aspect. Furthermore, the average score of the student achievement can be seen in Figure 1.

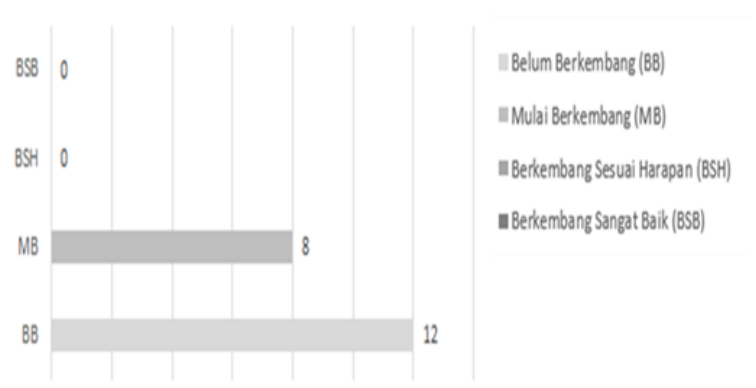

Figure 1. Student Achievements based on Percentage Category

Figure 1 shows that, from 20 students, 12 students were in the undeveloped category and 8 students were in the developing category. There was no student in the developed as expected category and well-developed category. Furthermore, according to each aspect of evaluation, the percentage of communication aspect gained the highest score, $44 \%$, while responsibility aspect gained the lowest percentage, 29\%, as depicted in Figure 2.

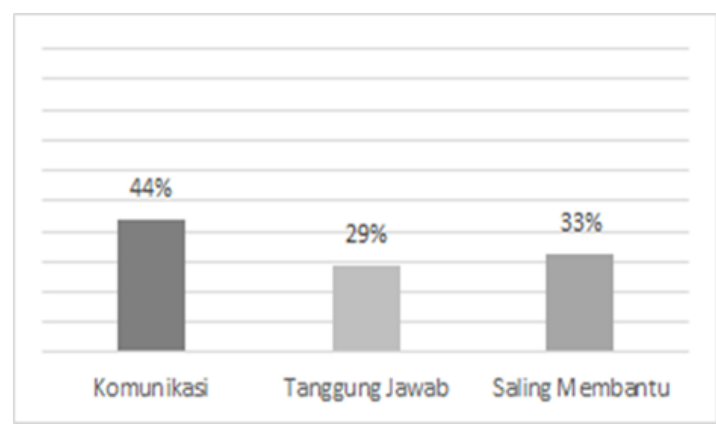

Figure 2. Percentage Result of the Students based on Each Aspect

In average, the lower-class student cooperative skills were in the undeveloped category and developing category. It indicates that more efforts are required to help students achieving the expected stage, the developed as expected and well-developed stages. The findings show that the students had tried to communicate the goal of the game proven by the highest percentage gained by the communication aspect, but it has not been conducted optimally. In addition, the responsibility of their roles in conducting the activity had not been well depicted or still in the undeveloped and developing stages. Therefore, it is expected that the result of the study can be the evaluation for the teachers in designing teaching program for the students.

Previous research argues that the cooperative skill is important specially to develop a person's life skill (Argyle, 2013; Jones, Greenberg, \& Crowley, 2015). Cooperative skill is crucial to be taught at elementary school, especially in a small class to equip the students face the future (Goddard, Goddard, \& Tschannen-Moran, 2007). According to the previous research, there are various learning alternatives that can be used by the teachers in designing learning programs for students to improve the student cooperative skills, including by using various learning models, such as cooperative learning or a programmed outbound activity (Agusta, 2018; $\mathrm{Ca}-$ sey \& Goodyear, 2015; Nurhayati \& Sugiharto, 2016).

\section{CONCLUSION}

The researcher concludes that, in average, the cooperative skill of the lower-class elementary school students was in the undeveloped category and developing category. According to the study, it becomes the evaluation for the teachers to provide an alternative learning that could stimulate the student cooperative skill. Furthermore, the utilization of the suitable technology could ease the student learning development evaluation process. 


\section{REFERENCE}

Agusta, A. R. (2018). Improving the Student's Cooperation and Environmental Care Skill using Outdoor Learning Strategy Outbound Variation. In 1st International Conference on Creativity, Innovation and Technology in Education (IC-CITE 2018). Atlantis Press.

Argyle, M. (2013). Cooperation (psychology revivals): The basis of sociability. Routledge.

Azhima, I. (2020). Arts and Crafts: Fun Activities to Train Early Childhood Cooperation. Early Childhood Research Journal (ECRJ), 2(2), 64 -68 .

Casey, A., \& Goodyear, V. A. (2015). Can cooperative learning achieve the four learning outcomes of physical education? A review of literature. Quest, 67(1), 56-72.

Dignath, C., Buettner, G., \& Langfeldt, H.-P. (2008). How can primary school students learn selfregulated learning strategies most effectively?: A meta-analysis on self-regulation training programmes. Educational Research Review, 3(2), 101-129.

Fraenkel, J. R., Wallen, N. E., \& Hyun, H. H. (2012). How To Design and Evaluate Research in Education (8th ed.). New York: McGraw-Hill Inc.

Goddard, Y. L., Goddard, R. D., \& TschannenMoran, M. (2007). A theoretical and empirical investigation of teacher collaboration for school improvement and student achievement in public elementary schools. Teachers College Record, 109(4), 877-896.

Jones, D. E., Greenberg, M., \& Crowley, M. (2015). Early social-emotional functioning and public health: The relationship between kindergarten social competence and future wellness. American Journal of Public Health, 105(11), 2283-2290.

Lai, E. R. (2011). Collaboration: A literature review. Pearson Publisher. Retrieved November, 11, 2016.

Lee, D., Huh, Y., \& Reigeluth, C. M. (2015). Collaboration, intragroup conflict, and social skills in project-based learning. Instructional Science, 43(5), 561-590.

Malik, A. A., \& Rubiana, I. (2019). Kemampuan Teknik Dasar Bolabasket: Studi Deskriptif Pada Mahasiswa. Journal of SPORT, 3(2), 79 $-84$.

Maryatun, I. B. (2008). Pemanfaatan kegiatan out- bound untuk melatih kerjasama (sebagai moral behavior) anak taman kanak-kanak. Retrieved September 1, 2020, from http:// staffnew.uny.ac.id/upload/132309079/ penelitian/Outbound+-+MOral+Behavior.pdf

Melis, A. P., \& Semmann, D. (2010). How is human cooperation different? Philosophical Transactions of the Royal Society B: Biological Sciences, 365(1553), 2663-2674.

Nur, L., Hafina, A., Rusmana, N., Suryana, D., \& Malik, A. A. (2019). Basic Motor Ability: Aquatic Learning for Early Childhood. ACTIVE: Journal of Physical Education, Sport, Health and Recreation, 8(2), 51-54.

Nur, L, Setiadi, P. M., Kusdinar, Y., \& Malik, A. A. (2019). Electronic rubric for motivation in physical education. Journal of Physics: Conference Series, 1318, 12129. https:// doi.org/10.1088/1742-6596/1318/1/012129

Nur, Lutfi, \& Malik, A. A. (2020). Motivasi Belajar Pendidikan Jasmani: Penerapan Teknik Memotivasi Teaching by Invitation pada Pendekatan Teknis. TEGAR: Journal of Teaching Physical Education in Elementary School, 3(2), 31-36.

Nur, Lutfi, Suherman, A., \& Subarjah, H. (2019). The Use of Global Positioning System (GPS) Polars to Determine Motion Intensity. Journal of Engineering Science and Technology, 14 (4), 2132-2139.

Nurhayati, N. F., \& Sugiharto, S. (2016). Outbound Game Model to Develop Interpersonal Competence of Primary School Students. The Journal of Educational Development, 4(2), 156-166.

Pangrazi, R. P., \& Beighle, A. (2019). Dynamic physical education for elementary school children. Human Kinetics Publishers.

Rokhayati, A., Nur, L., Gandana, G., \& Elan, E. (2016). Implementasi Pendekatan Taktis dalam Pembelajaran Pendidikan Jasmani Terhadap Motivasi, Kebugaran Jasmani dan Kemampuan Motorik. Jurnal Pendidikan Jasmani dan Olahraga, 1(2), 57-67. 